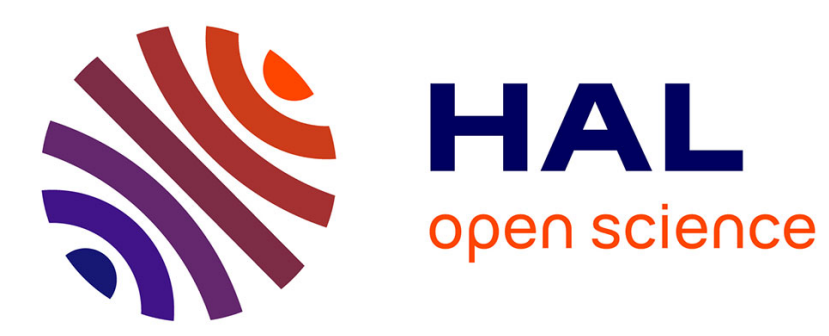

\title{
The thermal calculation of bone tissue slash modes by laser radiation
}

\author{
R. Letphullin, V. Igoshin
}

\section{To cite this version:}

R. Letphullin, V. Igoshin. The thermal calculation of bone tissue slash modes by laser radiation. Journal de Physique IV Proceedings, 1994, 04 (C4), pp.C4-274-C4-274. 10.1051/jp4:1994467 . jpa00252730

\section{HAL Id: jpa-00252730 https://hal.science/jpa-00252730}

Submitted on 1 Jan 1994

HAL is a multi-disciplinary open access archive for the deposit and dissemination of scientific research documents, whether they are published or not. The documents may come from teaching and research institutions in France or abroad, or from public or private research centers.
L'archive ouverte pluridisciplinaire HAL, est destinée au dépôt et à la diffusion de documents scientifiques de niveau recherche, publiés ou non, émanant des établissements d'enseignement et de recherche français ou étrangers, des laboratoires publics ou privés. 


\title{
The thermal calculation of bone tissue slash modes by laser radiation
}

\author{
R.R. LETPHULLIN and V.I. IGOSHIN
}

Samara Branch of P.N. Lebedev Physical Institute of Russian Academy of Sciences, Novo-Sadovaja Str. 221, Samara 443011, Russia

Power laser application in medicine is based on the different interaction forms between coherent light flow and living biological tissue. Laser beam causes photothermal, photomechanical, photoablative and photo chemical effects on living tissues. Thermal effects: photocoagulation and vaporization, that tend to the thermal necrosis of living blotissues, are the results of the intensive IR laser radiation Influence.

Thermal necrosis area is determined by the sizes of the primary and secondary tissue heat damage. The primary damage zone is characterized by biotissue material vaporization and carbonization processes that occur at sufficient high temperatures exceeding the temperature of phase tissue substance transitions. The secondary heat damage zone is determined by the albumen denaturation processes within comparatively low temperatures.

Thus, the final result of IR laser influence on biotissue is determined by the absorption volume, heating temperature that, in Its turn, depends on the energy parameters of laser beam, influence time, thermophysical tissue characteristics. In present paper the thermal calculation of bone tissue slagh modes by intensive IR lager radiation was fulfilled.

The threshold energy dengity of IR laser radiation and depth of the primary thermal damage (vaporization) of bone tissue are obtained on the basis of the solution of the heat equation. The calculations have shown that the effective slash of bone tissue with the narrow primary tissue damage zone $\sim 10 \mu \mathrm{m}$ is achieved for pulsed $\mathrm{CO}_{2}$ - laser radiation with duration $\sim 1 \mathrm{msec}$ and energy density $\sim 25 \mathrm{~J} / \mathrm{cm}^{2}$. At such times of exposure the depth of the primary damage is minimum and composes the value of the order of lager radiation wavelength. 